\title{
Orthodoxy and the myriad of challenges posed in the socio-economic sphere of Africa
}

\author{
His Grace Athanasios Akunda (RIP) $(\dagger)^{1}$ \\ Bishop of the Diocese of Kisumu in East Africa, Kenya \\ Catechist in Western Kenya, and Secretary in the office of the Archbishopric of Kenya \\ Member of the Association of the Theological Institutions of Eastern Africa (ATIEA) \\ Doi: https://doi.org/10.46222/pharosjot.10244
}

\begin{abstract}
The above title does not only pause a challenge to us but also displays before us the celebration of our achievements in Africa which are worthy of celebration. In this paper therefore I will address the problems of Africa on social and economic ground in relation to culture. I addressed this issue before and have discussed it at length with my brother-in-Christ father Evangelos who is an ethicist.
\end{abstract}

The social and economic problems are not entities in themselves but they each have a root cause and unless we address the roots we may not find any positive or lasting solutions. The root problem faced by many is a sense of cultural erosion which has led to lack of self-identity and thus resulted in many of the visible problems we are experiencing and we are desperately trying to find solutions to them. This problem may be self-inflicted as some of us may think but it is largely blamed on Religious missions in Africa from the past centuries to now, and also on the colonial powers who imposed themselves on Africa. The positive and negative effects of the two have left a great impact on an African way of thinking and acting. We have become aliens in our own African land, whether we are Black, Arab, White or Indian or whatever race of African.

As each day dawns we are faced with the consequences of the past mistakes and even in trying to find solutions we repeat the same mistakes on an ongoing basis. I will discuss my reflection on several of these bases; 1) dialogue with African culture a) identity crisis, b) Cultural erosion c) Cultural disintegration d) family unit and social unit break ups and confusion, e.) Generation gap f.) Economic gap g.) Religious bias and mission misrepresentation $\mathrm{h}$ ) indigenous languages, species i) Colonial Stigma j) Economic imbalance and trade unfairness.

\section{Dialogue with African culture(s)}

Many religions and denominations and a range of colonial powers, came to Africa with preconceived notions. This blocked them from knowing an African person better through dialogue with his or her culture, instead they tried to isolate Africans' from their culture(s) and imposed theirs upon us. This basic fact resulted due to the ignorance among the visitors and rebellion among the natives, very often leading to oppression, and then the often expected rebellion. As Africans we have to go back, and investigate our roots, who we are, for this will raise our consciousness and give us a different holistic stance and approach to the issues and also to ourselves, our surroundings and others with whom we share life on our beautiful continent. The most crucial problem that Africa is facing is not actually political or even economic, as portrayed in our physical eyes but it goes deeper than - and this is what I believe is an identity crisis that only our 'inner spiritual eyes' may see. The issue of identity has left many Africans especially the educated ones in 'space' without a proper place to 'land'. Hence we live a robotic existence on the one side and are often viewed as being primitive on the other side. We live in a state of self-denial, yet we do not accept fully to be the other person 
we really are. We deny our own space yet at the same time we cannot be fully accepted and even cannot fit into the space others try to place us in.

So who are we? This question is the problem and from this stems all the ignorance and problems that Africa faces today. The struggle to seek our own identity as Africans in the midst of all other natural and man-made pressures, is ours and the cause of our demise socially and also economically. Who is responsible? I do not know! But of course God is not responsible for our current dilemmas and challenges.

\section{Cultural Erosion}

African cultural richness and values have been eroded and 'flushed down the drain' through various channels ranging from foreign religious pietism and invasion, political correctness and the advent of globalization. This can be witnessed within our educational systems that are a ninety nine percent a duplicate of western style, an advocate of western culture, (I'm not opposing the good western education has done to Africa.) Despite the many good things Western education offers, we need to adop t a decolonial mindset that is ethically grounded. African schools and Universities, seems to produce confused members, and many students once after they graduate, feel they are neither Europeans, nor Africans. When we graduate from religious institutions we are neither complete Calvinists, Lutherans, Orthodox, Catholics etcetra, nor Complete traditional African religious adherents or Muslims etc. The balance has not been found yet and this is because of the curricula used which invariably contain a large percentage of material from without and less material from within local society.

Going further into this point let me take you back when colonialism and Christianity and even Islam were establishing their 'thrones' in various parts of Africa. The means used by both at times were often barbaric and humiliating, not even respecting the space and values of the hosts, resulting in social upheaval and spiritual and definitely political trauma. The theology and politics of oppression was introduced and all this was in the name of civilizing, or bringing a spiritualizing culture and so local life was 'swept under the carpet' and nothing good was said about all this at any point until the introduction of liberation theology and political activism.

This went on by the blatant reduction of the indigenous languages in public spaces like schools and offices, and via the promoting of 'exotic' languages in the name of being languages of business. If Greek and Latin were languages of business in the early centuries, and if English is now, then I do not see why we cannot make an African language a language of business rather than having to go through the English, French languages, or very soon Chinese.

Religious services and holy books are still read by the local people in the languages that are not entirely understood by them. Even the Holy book the Quran had to be read in Arabic to my grandmothers who did not have any real idea of what Arabic is, just to name few. We may have some reasons but we still have to consider that the languages of these people are holy too. Only a few spaces have been left to remind us of our cultural heritage, but even those so called heritage sites, are not open to the local people and especially not to our children who have no idea of their local cultures or history. These have instead have been left to tourists to visit for commercial purposes. In one way we pretend to preserve culture and yet the local people are side-lined in sharing in the wealth that accrues from cultural exploitation. The commercialization of peoples and cultures is a social problem though it may appear to be an economic solution. However, the paradox is the emigrants in Africa be they Chinese, Frencg, British, Jews, Greeks, Arabs, Portuguese, Indians, who despite their great involvement in political and religious struggles for the liberation of many African countries, and despite the fact that their Children are born here and become Africans, have tended to preserve their own mother-tongues and cultural backgrounds, and also religious understanding. To them their mother tongues are not an option but a pride and a necessity. This is because it is mainly through language that culture is preserved and promoted from one generation to the next. 
The opposite is that when an African goes overseas just for few years, he or she changes their accent and soon sounds like an American or British etc. When he or she visit their ancestral lands they cannot then even speak their own local language fluently. Children born outside their African communities always speak English to their grandmothers and grandfathers, and always view them as failures because they cannot speak English or whichever language. The only groups of outsiders in Africa trying to come out of this metal state of 'self-deleting' are the South Africans and West Africans especially the Ghanains' and Nigerians. Meet them out of Africa and their accents will definitely reveal their country to you. Other people who do not actually forget and are proud of their language are also the Kikuyu of Kenya. This simply reveals that for the most part, an African has lost pride in his or her own culture. Thus they are intimidating their own social status within the local community. This causes social malfunctions to arise within the various African communities.

At this time unlike before, many religions, especially Christianity in particular the Orthodox Church, is trying to help local people worship in their own languages, encouraging translations, and even sponsoring young men and women to study further and help is available in this field. Many South Africans of Greek or Cypriot descent go out of their way to support local adherents in preserving their local culture through a range of initiatives. This is commendable indeed. Enculturation is also a process of mission aimed at bridging this gap. However, this is just one step of many steps that need to be taken, and more must be done.

\section{Family Unit system collapse}

A family unit is a very important element of our African society and even our piety. Every aspect be it social, political, or religious rests upon family bonds for its success. Family is the link of the past, present and the future links also an African to the local surroundings. This is why marriage and courtship was not an individual or household secret event but a concern of the whole community. Once marriage took place separation was not permitted. It was the duty of the elders to preserve and to keep the couple as together as possible, to celebrate the coming of the children and always call upon the mighty power through the ancestors to protect the clan. The Bible also says that let no one separate what God has put together. The conscience of the family is preserved in local rituals, feasts, fasts and ceremonies. In this culminates the social, economic, and religious aspect which to this time has been dismantled in many parts of Africa, by foreign interventions and sadly by many African leaders who are ultra-capitalistic and self-serving, reaping benefits from political overlords, but now thus pandering to the whims of the now economic colonialists- the multinational corporations.

Development of Cities and even townships (history of townships in South Africa) has tended to break this command of God and separated the families. Men had to leave home to work far from away their families and live in compounds on mines or shacks, and while there, they either forget about their families at home or their wives forget about them. The earned a pittance and could not save enough to go home and visit as regularly as they would have liked to. They were paid lowly wages and had to pay rent and for other utilities, which made it impossible to save and take care of their families as they needed to. This kind of inflicted loneliness leads day by day to divorce, out of wedlock children, resulting in the total disintegration of the family structure. Other than unfaithfulness, also this problem affects children who mostly grew up without parental care, needed intimacy, and ethically based discipline.

After colonialism/apartheid, our governments still continue to develop cities, and create many job opportunities, but in the process they ignore the rural areas and so many men and women are forced to migrate to urban areas for survival and in the process, temptation gets them on the way. While in town landlords exploit them by unreasonable and extremely high house rents, however, the governments seems not to be controlling the rents in town which are 
extremely expensive and exploitative. People are forced to share small apartments in order to share the costs of living, these lead to congestion which is not only an economic but also a social and hygiene problem. There are no low cost rental houses in cities for example the city of Johannesburg is devoid of such sites.

There is also a social problem where older people who are seen as being unproductive are either abused, neglected or left to die in the old age homes. This is not an African way, in traditional African society old people were the custodian of the oral traditions and culture, they were preserved for advice and wisdom, it was the duty of the children and grandchildren to take to their blossom their old parents and grannies till they reposed. Old age was a blessing, but now everyone is scared to get old and even to retire. This a social and an economic problem especially in Africa. The spirit of African Ubuntu has been eroded and all black youth now seek American jeans and western culture and its music etc.

As religions have power to teach and convince and even to develop, the issues should not only be left to the governments to tackle, but all of us together should ensure that there is uniform development in both cities and rural areas, and we need to discourage the mentality that only good jobs can be found in cities. We can make villages become cities within their own locality, where they will find jobs, then they won't spend much and they will be with their families and live the African way.

\section{Economic gap}

The communal spirit has been eroded by introduction of capitalism where we have to buy our survival; poor people always struggle and use all the means to survive even if it means using unorthodox means. There is no caring for each other because the spirit of "A person is a person because of people" has vanished. The powerful who are uncertain of the future, keep on accumulating, so that they can continue holding their respected status in society and this included wealthy blacks. This is why we have corruption but it was introduced by systems like capitalism that again dismantled the African societal structure. This economic gap between the poor and the rich and an imbalanced distribution of wealth has affected the African individuals' economy. While African Governments get intoxicated by working on statistics to display the growth of economy internationally, many people go without food and water and other basic needs, while others spend money buying arms, people die of starvation and diseases that can be treated, while many governments complain of poverty, they keep huge salaries for their VIPs and political party cronies. Many blacks have accrued lot of benefits and we have had also had many incidents where many government employees have stashed huge amount of money in overseas banks -stolen from state coffers. When people are oppressed economically, they are forced to voice their cry by any means and language that can be understood. When people go through the tough times and religions do not say anything or act, then religion becomes useless or is viewed as part of the scheme. As governments and even prominent Church servants, we all talk about education for all, health for all, but we take our children not to public schools, but to private, and we go to private hospitals, if we do this, then it will be difficult to feel the pain since we just 'talk the talk' but we do not experience and feel the talk. We do not 'walk the walk'.

\section{Food shortage}

Food shortage may be natural and again in some areas it may indeed be manmade. During colonialism, African lands were taken and so Africans were only reduced to farm labourers and this was a factor that made many of them hate to be associated with farming or any 'dirty job' for it reminded them of the oppression they faced as farm workers for their 'masters'. They were not taught proper skills of farming, because there was a fear that the 'masters' farms would lack workers or and on the other hand the fear of creating an independence mindset in them. The 'masters' were the managers, and so after independence many Africans wanted 
to be managers but not to actually work in their farms. However in turn, we have many young people who go to school opting to study white collar courses where they can go to find office jobs in cities and look for larger wages to come and employ the unfortunate of their villages serving on their farms - this is an inherited colonial mentality, where blacks are now oppressing their own people.

Many young men I have met looking for jobs, are suffering in towns, and some have degrees but very few exist with agricultural degrees. They have big farms in the ancestral homes, which if they returned to they could utilize so that we do not have food shortages and we will have employment opportunities here. The mentality that working with the soil is a failure should be eliminated and agriculture should be encouraged at all levels of education, and not just to train as managers sitting and commanding others the way the masters used to do, but actually to get down to the farming and 'touch the soil' and come in contact with nature through the soil. This would reduce crime in towns, and the shortage of basic facilities in towns because of overcrowding and could also help with the utilization of idle lands and bring food to the marketplaces. It is shame for African countries to be importing food, as many other countries do when we have manpower and farming areas to exploit.

\section{Market and marketing}

The west has taken advantage of the above and now they make a lot of profit by giving us some food and commodities that are inconsumable in their own countries, for example the GMOs foods. There is a flood of cheap inferior Chinese market products in African markets to prevent the local producers selling their own products, laying down rules and tariffs that seem very difficult and complicated just to keep the weak of Africa from reaching the global business market. Just to second this we find the systemic elimination of indigenous seeds and breeds which are being replaced by exotic ones. The exotic breeds need fertilizers which at least paralyze the soil so that the soil becomes dependant on fertilizers and other chemicals, hence creating a market for foreign economic colonisation companies. In any case their actions also often violate the local environment which turns out to be harmful to the local people. Companies are set up in Africa because of cheap labour, and availability of raw material and in most cases the foreign companies aim only at making huge profit without considering the environmental catastrophes, these companies though they make huge profit, as they underpay the local people.

Meet an African Young man on the streets of Johannesburg, Nairobi. Mwanza, Harare, who has never been to America, and has no chance of being there, and even if he wants to it will be difficult, and see him putting on a T-shirt inscribed "Proud to be American" but you cannot find an American with the inscription "Proud to be African" - look at the movies and media, many of us like imported movies, full of wars (violence) and sex, yet our local music, movies, are not appreciated by us Africans, even the African Television stations have three-quarters of their movies, etc being foreign. This is dangerous as it does not only affect our young peoples' moral integrity but also social and cultural mindsets. We know very well that Media especially the Television and internet are very great 'poisons of mind' depending on what is displayed. As religions since we cannot do any major practical thing, but we can voice our concerns for we are the 'voice of the voiceless'.

\section{Religious unfairness}

Missions and introductions of other religions especially Christianity and Islam, have been the root cause of all the social havocs. First, Christianity came, preaching the same Christ yet divided. Proselytizing, crusading against each other using the African people and in the end there was a division among people in the same families but belonging to different denominations. The same happened when Islam came, preaching against Christianity, with mental Jihads, and physical upheavals which created enmity between people of same African 
families who in years had been together despite little differences here and there. It becomes social and religious disease when we continue to see these kinds of disagreements and campaigns against each other in the public eye of an African who in any way does not need a divided religion in any way. We are not a good example as religions, when we practice sexism, racism, ethnicity, and all the "Isms" and yet we preach against them. Is there an even distribution of our religions among the African people and other people? (This the question for each of us) Do we still look at others as non-believers, gentiles or barbarians, uncivilized, who do not actually need the whole bread but crumbs? Are all our brothers and sisters equal with us in relation to the glory of God?

The solution that many are trying to use in solving the issues posed is to preach the gospel of unity so as open the doors to all who create positive interest and condemn bad practices and fundamentalists who practice evils in the name of our religions. When there is a problem with religion, it also affects the social and economic life of the people the three cannot be separated.

Africa as a continent is not immune to religious and missionary competition. It is a testing ground for every new technology, and denomination. During the 'testing' period, no one cares what impact this will leave, just like scientists test on guinea pigs without having at heart the pigs' feelings and pain. Name any American denomination, or European denomination, you will find it in Africa. We still have those who do not believe that God is in Africa. This creates the fear of the new, and at the same time makes us reluctant to forget the past; then leading to syncretism and hypocrisy. It is funny and indeed also strange to find different churches, preaching the same Christ in a radius of five hundred meters from each other. When others are worshipping they can actually hear the other church service next door. This is confusion but it is not an African confusion. As religions we should not only invent and think that God is sending us to Africa to save Africa without acknowledging that we have God there, and we also have our own Christian denominations. This is a problem in Africa, because now people are more confused as to who is on the right side of the message about God.

We have interfaith and inter-religious dialogues, in order to know each other better. The World Council of Churches and other Church councils within particular locations are working on this and we can say that the more we understand each other the more we will respect the spaces each of us operate in.

\section{Conclusion}

These are few but crucial points that pass unnoticed sometimes, that underlie the social and economic problems, they are the root causes and so we have to heal them in order to save the situation. The attitude we have, colonial stigma, religious biasness, economic unfairness. Cultural disintegration, local language disintegration, unethical actions and immoral behaviours, are the major problems in Africa and should be our basic fighting targets to sort out and then slowly we will have the right things in place otherwise even if we take all the money of the world and pour it into Africa, our many problems will still remain. Our caring process in the Orthodox Church must be more integrated in nature, with a suitable exchange of resources and knowledge, while caring for the very poor, the downtrodden and needy. Compelled by our faith, Christ followers have attempted some incredible feats and changed the course of human history and today is no different. Poverty blemishes humanity, and it robs people of dignity. It reminds us that the world is broken at its core and needs redemption from the inside out. This is why we need to address poverty and build a community of loving believers.

The solutions is in our own hands and I'm sure each and every one of us is trying his or her best to improve on the above factors, for I believe, and agree with father Evangelos, that they are not new and still pose challenges to us- but we can and must prevail. We represent the people and to God we will account for every deed we inflict on those under our care. We agree 
that as priests in the service of God, we are amongst the main transformation actors in the challenge of socio-economic transformation. All the governments are instituted by God, and they need the direction of God for safe and sane governing, the state is just a small world of the whole world of religion. The church in Africa needs to move itself to the centre-stage of the local development agenda of the continent while continuing with the Kerygma, koinonia and diakonia as was the case with our early African Church Fathers such as Origen, Augustine, Hippo of Carthage, Tertullian, Cyprian, Lactantius and others. Our faith must be a blessing and not a curse.

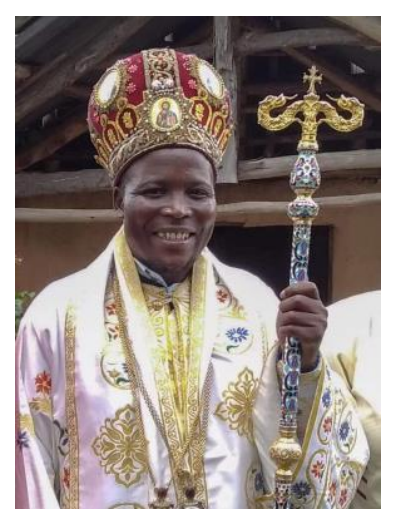

His Grace Athanasios Amos Akunda Masaba, (1971-1919) RIP (+) was the Bishop of the Diocese of Kisumu in East Africa, Kenya. Catechist in Western Kenya, and Secretary in the office of the Archbishopric of Kenya and he was also a Member of the Association of the Theological Institutions of Eastern Africa (ATIEA). He was a student at the "Makarios III" Seminary, and the Holy Cross Theological Academy in the USA. He was also a Doctor of Theology (DTH) from the UNISA State University of South Africa. He was ordained Deacon on April 121998 by His Eminence Metropolitan Seraphim of Zimbabwe and Presbyter on July 252002 by the same Hierarch as Metropolitan of Johannesburg and Pretoria. He was consecrated as Archimandrite on [January 18] 2010 by His Eminence Damaskinos Metropolitan of Johannesburg and Pretoria. He served in the Metropolis of Kenya, the Metropolis of Boston, USA, and the Missions of South Africa. He was also a Lecturer in Ceremonial rites, Patristics, Culture, Anthropology and Ecumenism at the "Makarios III" Patriarchal Seminary in Kenya. He was a member of the Association of the Theological Institutions of Eastern Africa (ATIEA). On November 24 2015, by proposal of His Beatitude Theodoros II (Choreftakis) of Alexandria, he was elected by the Holy Synod of the Patriarchate of Alexandria as Bishop of the newly-established Diocese of Kisumu. He was ordained by His Beatitude on December 62015. 